\title{
Genetic Polymorphisms of Hepatic ABC-Transporter in Patients with Hepatocellular Carcinoma
}

\author{
Minoru Fukuda ${ }^{1}$, Yasutsugu Kawahara ${ }^{3}$, Takeshi Hirota ${ }^{3}$, Setsuko Akizuki ${ }^{2}$, Shigeto \\ Murakami $^{1}$, Hisato Nakajima ${ }^{1}$, Ichiro Ieiri ${ }^{3}$, Akihiro Ohnishi ${ }^{1,2}$ \\ ${ }^{1}$ Division of Gastroenterology and Hepatology, Department of Internal Medicine, Jikei University School of Medicine, Komae, \\ Tokyo; ${ }^{2}$ Department of Laboratory Medicine, Daisan Hospital, Jikei University School of Medicine, Komae, Tokyo; ${ }^{3}$ Department of \\ Clinical Pharmacokinetics, Graduate School of Pharmaceutical Sciences, Kyushu University, Higashi-ku, Japan. \\ Email: ieiri-ttr@umin.ac.jp, aki-0275@jikei.ac.jp
}

Received May $15^{\text {th }}, 2010$; revised June $18^{\text {th }}, 2010$; accepted July $20^{\text {th }}, 2010$.

\begin{abstract}
We examined whether genetic polymorphisms of efflux transporters in hepatocytes are associated with susceptibility to develop hepatocellular carcinoma (HCC). Genetic polymorphisms of drug transporters expressed in hepatocytes were analyzed using DNA samples from hepatitis $C$ virus (HCV)-seropositive cirrhotic patients with HCC $(n=58)$, and allele and haplotype frequencies were compared with those in healthy subjects $(n=61)$. To search for single nucleotide polymorphisms (SNPs) in HCC susceptibility genes, 34 SNPs in 6 efflux transporters [MDR1 (ABCB1), ABCC1, $A B C C 2, A B C C 3, A B C G 2$ and $A B C B 11]$ were determined. No significant association was observed for any single SNP; however, some haplotypes in $A B C C 1$ and $A B C B 11$ were associated with HCC. Furthermore, three combinations of SNPs $(3435 C>T$ in $A B C B 1$ and $825 T>C$ in $A B C C 1),(3435 C>T$ in $A B C B 1$ and $-15281-15278 C T C T>$ delete in $A B C B 11)$, and (825T $>C$ in $A B C C 1$ and -15281 -15278CTCT $>$ delete in $A B C B 11)$ were significantly associated with $H C C$. The present study suggests that genetic variations of $A B C$ transporters such as $A B C B 1, A B C B 11$, and $A B C C 1$ are associated with susceptibility to develop HCC, implying that aberrant hepatic clearance of toxic substances may increase the risk of hepatocarcinogenesis. Further studies of how these polymorphisms are associated with phenotypic differences are warranted.
\end{abstract}

Keywords: Genetic Polymorphism, Drug Transporter, Hepatitis C Virus, Hepatocellular Carcinoma

\section{Introduction}

Hepatocellular carcinoma (HCC) is a frequent complication in advanced chronic liver disease, and is a major cause of death worldwide. In Japan, the high prevalence of HCC has largely been attributed to chronic infection by hepatitis virus, especially hepatitis $\mathrm{C}$ virus (HCV) [1-3]. HCV infection with persistent inflammation leads to sequential progression from acute to chronic hepatitis, cirrhosis, and eventually HCC in some cases. Since the development of HCC is a multistep process, numerous host factors (including gender, age, ethnicity, and stage of liver disease), viral factors (including viral genotype and levels), and environmental factors (including carcinogens, medications, and food) have been reported to be involved [4]. Further, oxidative products from endogenous and exogenous substances may accumulate in hepatocytes, possibly leading to hepatocarcinogenesis. One important protective function of the liver is the biliary and sinusoidal clearance of such endogenous and exogenous mutagenic/carcinogenic substances, preventing their accumulation in hepatocytes. This function is maintained by a drug efflux transporter system that comprises mainly the ABC-transporter proteins $[5,6]$. Therefore, mutation(s) of these proteins may impair the protective system against accumulation of hazardous compounds that may lead to HCC.

Recently, various drug transporters expressed in hepatocellular membranes have been studied in terms of vectorial direction, substrates, and the pharmacokinetics (PK)/pharmacodynamics (PD) of clinically relevant drugs. Among the efflux transporters, $\mathrm{ABC}$ transporters such as multidrug resistance 1 (MDR1, p-glycoprotein) are important in the detoxification of xenobiotics. For example, p-glycoprotein acts as an efflux pump for the carcinogen benzo $[a]$ pyrene in human breast cancer cells $[7,8]$.

An increasing number of single nucleotide polymorphisms (SNPs) in drug transporter genes are being iden- 
tified in humans [8], and may account for many of the significant individual differences in susceptibility to exogenous and endogenous mutagenic and carcinogenic insults. An example is $3972 \mathrm{C}>\mathrm{T}$ mutation in $A B C C 2$ (MRP2 gene); the risk of intrahepatic cholestasis of pregnancy for $3972 \mathrm{~T} / \mathrm{T}$ carriers has been reported to be 4-fold higher in comparison with $3972 \mathrm{C} / \mathrm{C}$ carriers [9]. With regard the mutation $421 \mathrm{C}>\mathrm{A}$ in $A B C G 2$ (BCRP gene), $421 \mathrm{C}>\mathrm{A}$ was associated with risks of diffuse large B-cell lymphoma and renal cell carcinoma [10,11]. Thus, the role of genetic polymorphisms of drug transporters in the development of HCC in patients infected with HCV is of interest. In this study, we selected 6 candidate genes encoding efflux transporters, which are involved in the hepatobiliary transport of endogenous and exogenous compounds in humans [8], and compared the allelic and haplotypic frequencies based on 34 SNPs between HCV-positive HCC patients and healthy subjects.

\section{Materials and Methods}

\subsection{Subjects and DNA Samples}

Fifty-eight Japanese cirrhotic patients with HCC were studied. Cirrhosis and HCC were diagnosed by liver biopsy or computed tomography and ultrasonography. Patient characteristics are summarized in Table 1. Peripheral blood was collected after obtaining written informed consent. The samples were numbered, unlinked, and tested anonymously. DNA was extracted by the standard protocol. The use of patient blood samples for this study had been approved by Jikei University Ethics Committee. For comparison, genomic DNA was also obtained from 61 Japanese healthy volunteers (aged 20 to 40 years). Each subject was physically normal and had no antecedent history of significant medical illness or hypersensitivity to any drug. Their body mass indices ranged be- tween 18 and $26 \mathrm{~kg} / \mathrm{m}^{2}$. Their health status was judged to be normal based on a physical examination, screening of blood chemistry, complete blood count, urinalysis, electrocardiogram, and chest X-ray conducted before the study. Written informed consent was obtained from all participants before the study.

\subsection{Genotyping}

Among various efflux transporters, we analyzed the following six ABC (ATP-binding cassette) transporters: multidrug resistance 1 (MDR1, p-glycoprotein; gene name, $A B C B 1)$; multidrug resistance-associated protein 1 (MRP1, $A B C C 1$ ), 2 (MRP2/cMOAT, $A B C C 2$ ) and 3 (MRP3, $A B C C 3$ ); breast cancer resistance protein (BCRP, $A B C G 2$ ); and bile salt export pump (BSEP, $A B C B 11$ ). The polymorphisms examined are listed in Table 2. All occur at certain frequencies or are reported to have functional variability [12-18]. Bile salt export pump (BSEP) contributes to the efflux of bile acids or bile salts across the canalicular membrane in the liver [19,20]. Although defects of the gene encoding BSEP can lead to a hereditary disorder, progressive familial intrahepatic cholestasis II (PFIC II) [21,22], all coding exons, all exon-intron junctions, and some 5' upstream regions were screened because we hypothesized that certain polymorphisms may be associated with lower transport activity.

$376 \mathrm{C}>\mathrm{T}$ and $421 \mathrm{C}>\mathrm{A}$ in $A B C G 2$, and $3435 \mathrm{C}>\mathrm{T}$ in $A B C B 1$ were determined using an ABI PRISM 7000 Sequence Detection System (Applied Biosystems, Foster, CA) with TaqMan SNP genotyping assays. $-1767 \mathrm{G}>\mathrm{A}$ in $A B C C 3$ were analyzed by polymerase chain reactionrestriction fragment length polymorphism (PCRRFLP). The other polymorphisms were detected by PCR-single strand conformation polymorphism (PCRSSCP). The accuracy of PCR-SSCP-based-genotyping

Table 1. Patients' characteristics.

\begin{tabular}{llll}
\hline variable & unit & Mean \pm SD & range \\
\hline gender & $\mathrm{M} / \mathrm{F}$ & $43 / 15$ & \\
age & years old & $70 \pm 7$ & $(53 \sim 87)$ \\
clinical stage (T.N.M) & I/II/III/IVa/IVb & $11 / 29 / 15 / 2 / 1$ & \\
Child-Pugh & $\mathrm{A} / \mathrm{B} / \mathrm{C}$ & $48 / 7 / 3$ & \\
AST & $(\mathrm{IU} / \mathrm{L})$ & $74 \pm 31$ & $(26 \sim 157)$ \\
ALT & $(\mathrm{IU} / \mathrm{L})$ & $68 \pm 62$ & $(11 \sim 459)$ \\
total protein & $(\mathrm{g} / \mathrm{dl})$ & $7.6 \pm 0.8$ & $(5.5 \sim 9.5)$ \\
albumin & $(\mathrm{g} / \mathrm{dl})$ & $3.7 \pm 0.5$ & $(2.5 \sim 4.6)$ \\
total bilirubin & $(\mathrm{mg} / \mathrm{dl})$ & $1.3 \pm 2.2$ & $(0.3 \sim 16.5)$ \\
prothrombin index & $(\%)$ & $79 \pm 12$ & $(44 \sim 100)$ \\
\hline
\end{tabular}

Data are mean \pm SD. Parenthesis indicates the range of data. $\uparrow$, TMN classification; $\ddagger$, Child-Pugh classification A, B, C; AST, asparate aminotransferase; ALT, alanine aminotransferase. Normal ranges (Central Chemical Laboratory, Daisan Hospital, The Jikei University School of Medicine, Tokyo): AST 5-28 IU/L; ALT 5-35 IU/L; total protein 6.8-8.3 g/dl; albumin 3.5-5.2 $\mathrm{g} / \mathrm{dl}$; total bilirubin $0.2-0.8 \mathrm{mg} / \mathrm{dl}$; prothrombin index $80-100 \%$ (prothrombin index obtained by dividing the prothrombin time of the patient by the reference value of control subjects). 
Table 2. Polymorphisms examined in the present study.

\begin{tabular}{|c|c|c|c|c|}
\hline gene & position & polymorphism & amino acid substitution & reference \\
\hline \multirow{2}{*}{$A B C B 1$} & exon 21 & $2677 \mathrm{G}>\mathrm{T} / \mathrm{A}$ & 893Ala $>$ Ser $/ \mathrm{Thr}$ & \multirow{2}{*}{ [9-11] } \\
\hline & exon 26 & $3435 \mathrm{C}>\mathrm{T}$ & 1145Ile (syn) & \\
\hline \multirow{6}{*}{$A B C C 1$} & exon 8 & $825 \mathrm{~T}>\mathrm{C}$ & $275 \mathrm{Val}$ (syn) & \multirow{6}{*}[12]{} \\
\hline & exon 9 & $1062 \mathrm{~T}>\mathrm{C}$ & 354Asn (syn) & \\
\hline & intron 9 & $1218+8 \mathrm{~A}>\mathrm{G}$ & - & \\
\hline & exon 13 & $1684 \mathrm{~T}>\mathrm{C}$ & 562Leu (syn) & \\
\hline & exon 16 & $2007 \mathrm{C}>\mathrm{T}$ & 669Pro (syn) & \\
\hline & exon 17 & $2168 \mathrm{G}>\mathrm{A}$ & $\operatorname{Arg} 723 \mathrm{Gln}$ & \\
\hline \multirow{6}{*}{$A B C C 2$} & promoter & $-24 \mathrm{C}>\mathrm{T}$ & - & \multirow{6}{*}[12]{} \\
\hline & exon 10 & $1249 \mathrm{G}>\mathrm{A}$ & $417 \mathrm{Val}>\mathrm{Ile}$ & \\
\hline & exon 18 & $2302 \mathrm{C}>\mathrm{T}$ & 768Arg $>$ Trp & \\
\hline & exon 18 & $2366 \mathrm{C}>\mathrm{T}$ & 789Ser $>$ Phe & \\
\hline & exon 28 & $3972 \mathrm{C}>\mathrm{T}$ & 1324Ile (syn) & \\
\hline & exon 31 & $4348 \mathrm{G}>\mathrm{A}$ & 1450Ala $>$ Thr & \\
\hline \multirow{2}{*}{$A B C C 3$} & promoter & $-1767 \mathrm{G}>\mathrm{A}$ & - & \multirow{2}{*}[13]{} \\
\hline & exon 2 & $135 \mathrm{G}>\mathrm{T}$ & 45Leu (syn) & \\
\hline \multirow{2}{*}{$A B C G 2$} & exon 4 & $376 \mathrm{C}>\mathrm{T}$ & $126 \mathrm{Gln}>$ stop & \multirow{2}{*}[14]{} \\
\hline & exon 5 & $421 \mathrm{C}>\mathrm{A}$ & $141 \mathrm{Gln}>$ Lys & \\
\hline$A B C B 11$ & promoter & $-15281-15278$ CTCT $>$ delete & - & {$[15]$} \\
\hline
\end{tabular}

was confirmed by direct sequencing using a Big-Dye Terminator Cycle Sequencing kit (Applied Biosystems). The primers and restriction enzymes used in this study are listed in Table 3. The primers designed for $A B C B 11$ were based on the following sequences; GenBank acession numbers AC008177.3 (for promoter and exons 1-21) and AC069137.6 (for exons 22-28) (Table 4). The specificity of all primers was confirmed by direct sequencing.

\subsection{Haplotype Analysis}

For each gene, a haplotype analysis was performed with Arlequin ver. 3.11 (http://cmpg.unibe.ch/software/arlequin3/). The Arlequin software package estimates haplotype frequencies using the expectation-maximization (EM) algorithm. Only polymorphisms, except those in intronic regions, with a relative frequency $>0.05$ were included in the analysis in either patients or healthy volunteers.

\subsection{Analysis of Combinations of Polymorphisms in Different genes}

In addition to the single gene testing, the influence of combinations of polymorphisms in different genes on HCC was assessed. In this analysis, we compared genotypic frequencies between subjects with and without variant types.

\subsection{Statistical Analysis}

All genotypes were tested as to whether they were dis- tributed according to the Hardy-Weinberg equilibrium. The association between different genotypes and the presence of HCC was evaluated using the chi-square test. For all tests, a $P$ value less than 0.05 was considered significant. The odds ratio and a $95 \%$ confidence interval (CI.) were also calculated.

\section{Results}

Table 5 shows the polymorphisms of interest identified in the 6 genes, together with their allelic frequencies. In $A B C B 11$, we identified 16 polymorphisms. Among them, $1331 \mathrm{C}>\mathrm{T}(444 \mathrm{Val}>\mathrm{Ala})$ in exon 13 and $2594 \mathrm{C}>\mathrm{T}$ (865Ala $>$ Val) in exon 21 were non-synonymous variants. In the single gene testing, all 95\% CI. values crossed 1.0, indicating no association between any SNPs and HCC.

Results of the haplotype assessment of HCC are shown in Table 6. Significant associations were observed in the $A B C C 1(p=0.010)$ and $A B C B 11(p=0.028)$ genes. In $A B C C 1$, seven haplotype patterns were assessed on the basis of five SNPs (i.e., 825T $>$ C, 1062T $>$ $\mathrm{C}, 1684 \mathrm{~T}>\mathrm{C}, 2007 \mathrm{C}>\mathrm{T}$, and $2168 \mathrm{G}>\mathrm{A}$ ). CCCCG and TTCCG were the most frequently observed haplotypes in the patient and control groups (CCCCG: 0.37 vs. 0.23 ; TTCCG: 0.25 vs. 0.36 ), respectively. The frequency of TTCCA was 0.06 in patients, while this haplotype was not observed in the control group. In $A B C B 11$, eight haplotypes were assessed based on five polymorphisms $(-15281-15278$ CTCT $>$ delete, $108 \mathrm{~T}>\mathrm{C}, 807 \mathrm{~T}>\mathrm{C}$, $1331 \mathrm{~T}>\mathrm{C}$, and 3084A $>$ G). DelTTCG was the most fre- 
Table 3. Primer sets for PCR-SSCP and PCR-RFLP determinations, and RELP conditions.

\begin{tabular}{|c|c|c|c|}
\hline gene & polymorphism & forward primer & reverse primer \\
\hline$A B C B 1$ & $2677 \mathrm{G}>\mathrm{T} / \mathrm{A}$ & 5'-TACCCATCATCATTGCAATAGCAG-3' & 5'-TTTAGTTTGACTCACCTTCCC-3' \\
\hline \multirow{5}{*}{$A B C C 1$} & $825 \mathrm{~T}>\mathrm{C}$ & 5'TGGTAGGGGGCTGCATCTCTG 3' & 5'CAAAGCCAAGGAGGGAAAATG 3' \\
\hline & $\begin{array}{l}1062 \mathrm{~T}>\mathrm{C} \\
1218+8 \mathrm{~A}>\mathrm{G}\end{array}$ & 5'CCCCCACGTGTCACAAGTCAT 3' & 5'CACGCTGGCCCCAGAGTAACC 3' \\
\hline & $1684 \mathrm{~T}>\mathrm{C}$ & 5'ACTCGGGGCACAGCAGTCAGC 3' & 5'GAACCCCAAGGCCCCCTCTCG 3' \\
\hline & $2007 \mathrm{C}>\mathrm{T}$ & 5'TAGCCCGGCAGGCCTCATTCA 3' & 5'AGCTTTTCCTCAGACCACCAG 3' \\
\hline & $2168 \mathrm{G}>\mathrm{A}$ & 5'GTGGGCCAGCTGTTGTCTCGT 3' & 5'GCGGCAACAGCTGACTGATTC 3' \\
\hline \multirow{5}{*}{$A B C C 2$} & $-24 \mathrm{C}>\mathrm{T}$ & 5'-CTGTTCCACTTTCTTTGATGA-3' & 5'-TCTTGTTGGTGACCACCCTAA-3' \\
\hline & $1249 \mathrm{G}>\mathrm{A}$ & 5'-AGCCACAAAGTAGCAGTGAGG-3' & 5'-TTACCCACAGAGAGCCACCTA-3' \\
\hline & $\begin{array}{l}2302 \mathrm{C}>\mathrm{T} \\
2366 \mathrm{C}>\mathrm{T}\end{array}$ & 5'-GGAGTAGTGCTTAATATGAAT-3' & 5'-CССАССССАССТTТАТАТСТT-3' \\
\hline & $3972 \mathrm{C}>\mathrm{T}$ & 5'-AGGAGCTAACACATGGTTGCT-3' & 5'-GGGTTAAGCCATCCGTGTCAA-3' \\
\hline & $4348 \mathrm{G}>\mathrm{A}$ & 5'-AGGAGCTAACACATGGTTGCT-3' & 5'-GGGTTAAGCCATCCGTGTCAA-3' \\
\hline \multirow[t]{2}{*}{$A B C C 3$} & $-1767 \mathrm{G}>\mathrm{A}^{\dagger}$ & 5'-GCTTAGATATCACCCTGTCCA-3' & 5'-TCCACTCATCCACACATACCC-3' \\
\hline & $135 \mathrm{G}>\mathrm{T}$ & 5'-GGCTGCCACAGCACTAAACTG-3' & 5'-CCAGCCCCATCGGTAGGAGAT-3' \\
\hline
\end{tabular}

Table 4. Primer sets for the PCR of $A B C B 11$.

\begin{tabular}{lll}
\hline position & \multicolumn{1}{c}{ forward primer } & \multicolumn{1}{c}{ reverse primer } \\
\hline promoter & 5'-TCCACTCCAGGTTCAGCTTC-3' & 5'-CTCTGCCTCAGGAATCTTACA-3' \\
exon 1 & 5'-CTCAATTTGCCTCTCGTTCCA-3' & 5'-GCATCCTGTAAGTTTCTATCC-3' \\
exon 2 & 5'-TTTCGTTTGGCTACTTTGATT-3' & 5'-ATACTTCTACCTACTGTTGCT-3' \\
exon 3 & 5'-ATTTCTTAATGACTGCGTTGC-3' & 5'-GGGGACATTTGAACCTAACCT-3' \\
exon 4 & 5'-GTGGTCTTTAAATCCTTATGT-3' & 5'-TGTGATGACTTTCCTTACAAA-3' \\
exon 5 & 5'-GATGATCTCTGAACCCTTTGT-3' & 5'-CAGCCAGTAAAATCCCCTCTA-3' \\
exon 6 & 5'-TGAACATTCTTTTCCCTCTTT-3' & 5'-ACATTGCATCTCATTGTAGTG-3' \\
exon 7 & 5'-CTGAATTACTTTCCCCCTTTT-3' & 5'-CATATTTGACAGTGTATTACT-3' \\
exon 8 & 5'-GTTTAAAAGGGAAAGACTGAG-3' & 5'-ATAATTATGTTGCTAACTGTA-3' \\
exon 9 & 5'-AATGACAGACTGACTTACCTA-3' & 5'-ACTCTGCTTAGCTCCCTCTTG-3' \\
exon 10 & 5'-ACTCAAGCATTTTGTCTTCAC-3' & 5'-ATGTCTCGGTCAATAAGTCCA-3' \\
exon 11 & 5'-GGAAGACCCAAATGATAGTAA-3' & 5'-GAATTAAGGGCCTTGCGATAG-3' \\
exon 12 & 5'-TCTTAGTTTGAGTTTACACTG-3' & 5'-ATTTACTATTCTGGGGAACAG-3' \\
exon 13 & 5'-GGGGCATACATAAACGCACAC-3' & 5'-ACTATGCATGCCAGGACAGTC-3' \\
exon 14 & 5'-CTGCCCATTGGTCAAGTATGA-3' & 5'-CTATGACCTCTTAGTTTCTCC-3' \\
\hline
\end{tabular}




\begin{tabular}{|c|c|c|}
\hline exon 15 & 5'-САТСАААТТСТТТТСССТТСА-3' & 5'-GGACCTGTAAAATGGACTAAG-3' \\
\hline exon 16 & 5'-TGAAATGATGCAAAGGTCAGT-3' & 5'-TAGAAAACCGTAAAGCACTAT-3' \\
\hline exon 17 & 5'-TCTACTTGGATATGGTTCTGT-3' & 5'-ATTTGGAAAGCTTGTAATCTG-3' \\
\hline exon 18 & 5'-TAGCTCTGTCAAACCTAACCT-3' & 5'-TAGTCTGACTTGAAACACTGC-3' \\
\hline exon 19 & 5'-CCATAGACATTTGAGGTCACT-3' & 5'-ATGAAAACAAAGAGCGGACTT-3' \\
\hline exon 20 & 5'-CAGATCCACAGCTTACATTAG-3' & 5'-AAAACATGAAGAGGGAGATG-3' \\
\hline exon 21 & 5'-GTAAGAAATGTTATTTTTCAG-3' & 5'-CAATCCCACTGGTCCCTATTC-3' \\
\hline exon 22 & 5'-GTAATTGGTAAAAGCGACTGT-3' & 5'-TTAAGTGTGCCTGTCTTGTGG-3' \\
\hline exon 23 & 5'-CCACTGAAATGTCACGAAAGG-3' & 5'-TAACTGACAGAACCAGGCTAT-3' \\
\hline exon 24 & 5'-ACCAACCACGCCACCCTGCTC-3' & 5'-TTTGTTCAACTCCCACTTATG-3' \\
\hline exon 25 & 5'-AGGCTTCAGTAAGAGCATCTC-3' & 5'-AGCCCACTTTTAGGGGTTGGA-3' \\
\hline exon 26 & 5'-CTGCTGGAATTCTAAAAACCT-3' & 5'-TCCCCATCCTTGTCTCTCATA-3' \\
\hline exon 27 & 5'-GGAGGACTCACTCACTGTTCC-3' & 5'-TGCCATTTTATTAAGGACAAA-3' \\
\hline exon 28 & 5'-TTGCATCAАCТTTCCAТCТTC-3' & 5'-ССССТGTAACTGGTGCGTCAT-3' \\
\hline
\end{tabular}

Table 5. Polymorphisms detected in the six genes of interest with their allelic frequencies.

\begin{tabular}{|c|c|c|c|c|c|c|c|}
\hline \multirow{3}{*}{ gene } & \multirow{3}{*}{ position } & \multirow{3}{*}{ polymorphism } & \multicolumn{4}{|c|}{ allelic frequency $(\%)$} & \multirow{3}{*}{ odds ratio ( $95 \%$ c.i.) } \\
\hline & & & \multicolumn{2}{|c|}{$\begin{array}{l}\text { patients } \\
(\mathrm{n}=58)\end{array}$} & \multicolumn{2}{|c|}{$\begin{array}{l}\text { healthy subjects } \\
\qquad(\mathrm{n}=61)\end{array}$} & \\
\hline & & & $\mathrm{r}$ & $\mathrm{v}$ & $\mathrm{r}$ & $\mathrm{v}$ & \\
\hline \multirow{2}{*}{$A B C B 1$} & exon 21 & $2677 \mathrm{G}>\mathrm{T} / \mathrm{A}$ & 45.5 & 54.5 & 50.8 & 49.2 & $1.24(0.74-2.07)$ \\
\hline & exon 26 & $3435 \mathrm{C}>\mathrm{T}$ & 51.8 & 48.2 & 63.3 & 36.7 & $1.61(0.95-2.72)$ \\
\hline \multirow{6}{*}{$A B C C 1$} & exon 8 & $825 \mathrm{~T}>\mathrm{C}$ & 50.9 & 49.1 & 61.5 & 38.5 & $1.54(0.92-2.59)$ \\
\hline & exon 9 & $1062 \mathrm{~T}>\mathrm{C}$ & 50.9 & 49.1 & 61.5 & 38.5 & $1.54(0.92-2.59)$ \\
\hline & intron 9 & $1218+8 \mathrm{~A}>\mathrm{G}$ & 50.9 & 49.1 & 61.5 & 38.5 & $1.54(0.92-2.59)$ \\
\hline & exon 13 & $1684 \mathrm{~T}>\mathrm{C}$ & 25.5 & 74.5 & 27.9 & 72.1 & $1.13(0.63-2.03)$ \\
\hline & exon 16 & $2007 \mathrm{C}>\mathrm{T}$ & 98.2 & 1.8 & 93.4 & 6.6 & $0.26(0.05-1.25)$ \\
\hline & exon 17 & $2168 \mathrm{G}>\mathrm{A}$ & 89.3 & 10.7 & 90.2 & 9.8 & $1.10(0.47-2.56)$ \\
\hline \multirow{6}{*}{$A B C C 2$} & promoter & $-24 \mathrm{C}>\mathrm{T}$ & 83.6 & 16.4 & 84.4 & 15.6 & $1.00(0.49-2.01)$ \\
\hline & exon 10 & $1249 \mathrm{G}>\mathrm{A}$ & 82.8 & 17.2 & 85.2 & 14.8 & $1.20(0.60-2.41)$ \\
\hline & & $2302 \mathrm{C}>\mathrm{T}$ & 100.0 & 0.0 & 100.0 & 0.0 & - \\
\hline & exon 18 & $2366 \mathrm{C}>\mathrm{T}$ & 99.2 & 0.8 & 100.0 & 0.0 & - \\
\hline & exon 28 & $3972 \mathrm{C}>\mathrm{T}$ & 81.0 & 19.0 & 82.0 & 18.0 & $1.06(0.55-2.05)$ \\
\hline & exon 31 & $4348 \mathrm{G}>\mathrm{A}$ & 100.0 & 0.0 & 100.0 & 0.0 & - \\
\hline \multirow{2}{*}{$A B C C 3$} & promoter & $-1767 \mathrm{G}>\mathrm{A}$ & 85.5 & 14.5 & 83.3 & 16.7 & $0.85(0.42-1.74)$ \\
\hline & exon 2 & $135 \mathrm{G}>\mathrm{T}$ & 96.4 & 3.6 & 97.5 & 2.5 & $1.44(0.32-6.60)$ \\
\hline
\end{tabular}


Continued Table 5

\begin{tabular}{|c|c|c|c|c|c|c|c|}
\hline \multirow{2}{*}{$A B C G 2$} & exon 4 & $376 \mathrm{C}>\mathrm{T}$ & 97.3 & 2.7 & 98.4 & 1.6 & $1.65(0.27-10.1)$ \\
\hline & exon 5 & $421 \mathrm{C}>\mathrm{A}$ & 71.4 & 28.6 & 73.8 & 26.2 & $1.13(0.63-2.00)$ \\
\hline \multirow{16}{*}{$A B C B 11$} & promoter & $\begin{array}{c}-15281 \_-15278 \text { CTCT }> \\
\text { delete }\end{array}$ & 62.9 & 37.1 & 74.6 & 25.4 & $1.73(0.99-3.01)$ \\
\hline & intron 3 & exon $3+84 \mathrm{C}>\mathrm{T}$ & 92.2 & 7.8 & 95.1 & 4.9 & $1.63(0.56-4.72)$ \\
\hline & exon 4 & $108 \mathrm{~T}>\mathrm{C}$ & 73.3 & 26.7 & 71.3 & 28.7 & $0.91(0.51-1.60)$ \\
\hline & intron 4 & exon $4+188 \mathrm{~A}>\mathrm{G}$ & 100.0 & 0.0 & 99.2 & 0.8 & - \\
\hline & intron 4 & exon $4+196 \mathrm{~T}>\mathrm{C}$ & 100.0 & 0.0 & 99.2 & 0.8 & - \\
\hline & exon 5 & $270 \mathrm{~T}>\mathrm{C}$ & 92.2 & 7.8 & 95.1 & 4.9 & $1.63(0.56-4.72)$ \\
\hline & exon 9 & $807 \mathrm{~T}>\mathrm{C}$ & 73.3 & 26.7 & 70.5 & 29.5 & $0.87(0.50-1.54)$ \\
\hline & exon 10 & $1030 \mathrm{G}>\mathrm{A}$ & 100.0 & 0.0 & 99.2 & 0.8 & - \\
\hline & intron 11 & exon $11+57 \mathrm{C}>\mathrm{A}$ & 100.0 & 0.0 & 99.2 & 0.8 & - \\
\hline & exon 13 & $1331 \mathrm{C}>\mathrm{T}$ & 23.3 & 76.7 & 25.4 & 74.6 & $1.12(0.62-2.03)$ \\
\hline & intron 13 & exon $13+70 \mathrm{~T}>\mathrm{C}$ & 23.3 & 76.7 & 25.4 & 74.6 & $1.12(0.62-2.03)$ \\
\hline & intron 18 & exon $18+97 \mathrm{~A}>\mathrm{G}$ & 70.7 & 29.3 & 63.1 & 36.9 & $0.71(0.41-1.22)$ \\
\hline & intron 18 & exon $18+98 \mathrm{~T}>\mathrm{C}$ & 70.7 & 29.3 & 63.1 & 36.9 & $0.71(0.41-1.22)$ \\
\hline & intron 18 & exon $19-17 \mathrm{C}>\mathrm{A}$ & 40.5 & 59.5 & 39.3 & 60.7 & $0.95(0.57-1.60)$ \\
\hline & exon 21 & $2594 \mathrm{C}>\mathrm{T}$ & 99.1 & 0.9 & 99.2 & 0.8 & $1.05(0.07-17.0)$ \\
\hline & exon 24 & $3084 \mathrm{~A}>\mathrm{G}$ & 39.7 & 60.3 & 38.3 & 61.7 & $0.95(0.56-1.60)$ \\
\hline
\end{tabular}

In $A B C B 11$ gene, numbering of nucleotides is according to the GenBank accession numbers AC008177.3 (promoter and exons 1-21) and AC069137.6 (exons 22-28). Positions of polymorphisms are counted with respect to the BSEP translation initiation site being +1 and the 5 '-following base being -1 . r: reference type, v: variant type.

Table 6. Haplotype assessment and HCC.

\begin{tabular}{ccc}
\hline \multirow{2}{*}{$A B C$ 1 haplotype pattern } & \multicolumn{2}{c}{ frequency } \\
\cline { 2 - 3 } & patient & control \\
\hline C C C C G & 0.37 & 0.23 \\
T T C C G & 0.25 & 0.36 \\
T T T C G & 0.19 & 0.19 \\
C C T C G & 0.07 & 0.07 \\
T T C C A & 0.06 & 0.00 \\
C C C C A & 0.05 & 0.08 \\
T T C T G & 0.02 & 0.05 \\
\cline { 2 - 3 }$A B C B 1$ 1 haplotype pattern & $\chi^{2}=16.75(p=0.010)$ \\
\cline { 2 - 3 } Del T T C G & \multicolumn{2}{c}{ frequency } \\
C C C C G & 0.24 & control \\
C T T T G & 0.15 & 0.17 \\
C T T C A & 0.13 & 0.12 \\
C T T T A & 0.13 & 0.06 \\
C C C C A & 0.10 & 0.10 \\
Del T T C A & 0.08 & 0.15 \\
C T T C G & 0.06 & 0.05 \\
& 0.06 & 0.19 \\
\cline { 2 - 3 } & \multicolumn{2}{c}{$\chi^{2}=15.69(p=0.028)$} \\
\hline & &
\end{tabular}

quently observed haplotype (0.24) in the patient group, while CTTCG was the major pattern (0.19) in the control group. The frequency of CTTCA was higher in patients than in controls $(0.13$ vs. 0.06$)$, but the frequency of CCCCA was lower in patients than in control group $(0.08$ vs. 0.15$)$.

We tested the association of all combinations of polymorphisms of different genes with HCC, and identified three as candidate markers for susceptibility to HCC (Table 7). All candidates were a combination of two of the following three efflux $\mathrm{ABC}$ transporters; $A B C B 1$ $(3435 \mathrm{C}>\mathrm{T}), A B C C 1(825 \mathrm{~T}>\mathrm{C})$ and $A B C B 11(-15281$ -15278 CTCT $>$ delete). The frequencies of the three mutations in the three genes in both patients and healthy subjects obeyed the Hardy-Weinberg law, indicating normal distribution of the genetic mutations in the subjects of our study. The three combinations were: $[A B C B 1$ and $A B C C 1$, odds ratio $(95 \%$ CI. $)=4.44$ (1.13-17.5)], [ABCB1 and $A B C B 11,4.47(1.26-15.9)]$, and [ABCC1 and $A B C B 11,3.79$ (1.21-11.9)].

\section{Discussion}

Drug transporters can affect the absorption, distribution, and excretion of not only drugs but also mutagens and carcinogens, as well as their metabolites. The genetic polymorphisms in drug transporters have been linked to 
Table 7. Association of combination of efflux transporter polymorphisms with HCC.

\begin{tabular}{|c|c|c|c|c|c|}
\hline \multirow[t]{2}{*}{ combined polymorphism } & \multicolumn{2}{|c|}{$\begin{array}{l}\text { patients } \\
(\mathrm{n}=58)\end{array}$} & \multicolumn{2}{|c|}{$\begin{array}{l}\text { healthy subjects } \\
\qquad(\mathrm{n}=61)\end{array}$} & \multirow[t]{2}{*}{ odds ratio $(95 \%$ c.i. $)$} \\
\hline & $\mathrm{r}$ & $\mathrm{v}$ & $\mathrm{r}$ & $\mathrm{v}$ & \\
\hline$A B C B 13435 \mathrm{C}>\mathrm{T} \& A B C C 1825 \mathrm{~T}>\mathrm{C}$ & 3 & 30 & 12 & 27 & $4.44(1.13 \sim 17.5)$ \\
\hline $\begin{array}{c}A B C B 13435 \mathrm{C}>\mathrm{T} \& \\
A B C B 11-15281 \_-15278 \mathrm{CTCT}>\text { delete }\end{array}$ & 4 & 23 & 14 & 18 & $4.47(1.26 \sim 15.9)$ \\
\hline $\begin{array}{c}A B C C 1825 \mathrm{~T}>\mathrm{C} \& \\
A B C B 11-15281 \_-15278 \mathrm{CTCT}>\text { delete }\end{array}$ & 6 & 26 & 14 & 16 & $3.79(1.21 \sim 11.9)$ \\
\hline
\end{tabular}

We compared frequencies between subjects homozygotes for the reference allele (r) and subjects with at least one variant (v) allele in each gene.

inter-individual differences in $\mathrm{PK} / \mathrm{PD}$ profiles of clinically relevant drugs [8], leading to expectations that these polymorphisms may also account for significant individual differences in susceptibility to exogenous and endogenous mutagenic and carcinogenic insults. In fact, in the clinical setting, some cases of HCV-related cirrhosis progress to HCC, while others do not. Among drug transporters, $\mathrm{ABC}$ transporters potentially affect the risk of carcinogenesis, because their substrates include carcinogens such as benzo $[a]$ pyrene and p-glycoprotein, nitrosamine, 4-(methylnitrosamino)-1-(3-pyridyl)-1-butanone and MRP1 [23], and 2-amino-1-methyl-6-phenylimidazo[4,5-b]pyridine and BCRP [24].

The pharmacogenomic association of $3435 \mathrm{C}>\mathrm{T}$ in $A B C B 1$ with renal epithelial tumors [25] and colorectal cancers has been studied [26]. However, to our knowledge, there are very few reports on its association with HCC. Although both previous studies indicated that the $3435 \mathrm{~T}$ allele was a risk factor for developing cancers, we found no association between any SNP of any gene of interest and HCC in the present study, suggesting that it is difficult to predict HCC based on single SNP in a single gene (Table 5).

Next, we conducted a haplotype assessment and identified $A B C C 1$ and $A B C B 11$ as susceptibility genes of hepatic carcinogenesis. MRP1 transports various chemical compounds. Aflatoxin $\mathrm{B}_{1}\left(\mathrm{AFB}_{1}\right)$, a mycotoxin, is a contaminant of certain food products including grains and peanuts. $\mathrm{AFB}_{1}$ has been shown to be carcinogenic in the lungs as well as the liver [27]. The high-affinity transport of glutathione conjugates of $\mathrm{AFB}_{1}$ epoxide has been demonstrated using human MRP1-enriched membrane vesicles [28]. However, the incidence of tumors in $\operatorname{Mrp1(-/-)~versus~} \operatorname{Mrp} 1(+/+)$ mice 12 months after eightweek exposure to $\mathrm{AFB}_{1}$ revealed that the expression of MRP1 provided no protection to the lungs or liver from the carcinogenicity of this compound [29]. Although $\mathrm{AFB}_{1}$ might be a substrate for MRP1 in vivo, function- ally redundant $\mathrm{ABC}$ transporters may compensate for MRP1 in MRP1-deficient animals. Since the level of MRP1 in human liver is relatively low in comparison with that in other organs (e.g., lungs and kidneys), [30] MRP1 is likely to act as a barrier in cooperation with other transporters in the liver.

Since chemotherapy has long been a standard treatment to reduce the growth of HCC, the development of multidrug resistance by $\mathrm{ABC}$ transporters is a major obstacle to its success. Bonin et al. [31] investigated the expression of MRP1, MRP2, MRP3, p-glycoprotein, and MDR3 in paraffin-embedded tissues by quantitative RT-PCR. They found that multidrug resistance proteins, in particular MRP1, MRP2 and p-glycoprotein, were increased in HCC. The extent of MRP1 expression was similar in neoplastic and perineoplastic tissue, but this was not the case for MRP2 and p-glycoprotein. The expression of MRP1 altered neoplastic proliferation with some correlation to malignancy [32].

Recently, Knisely et al. [33] studied the association between PFIC, diagnosed from immunohistochemical evidence of a deficiency of BSEP and a mutational analysis of the $A B C B 11$ gene, and HCC in 11 unrelated children, and concluded that BSEP deficiency increases the risk of HCC in early life. Increased intracellular concentrations of bile acids have reported to be carcinogenic in human gastrointestinal cancer [34]. Although we had no PFIC patients and no young children, these reports support our findings of an association between the transport capability of BSEP and HCC.

In this study, after analyzing all the combinations of SNPs for all the transporter genes examined, three combinations of SNPs in two different genes were detected as candidate markers for susceptibility to HCC: $3435 \mathrm{C}>\mathrm{T}$ in $A B C B 1$ and $825 \mathrm{~T}>\mathrm{C}$ in $A B C C 1,3435 \mathrm{C}>\mathrm{T}$ in $A B C B 1$ and $-15281-15278 \mathrm{CTCT}>$ delete in $A B C B 11$, and $825 \mathrm{~T}>\mathrm{C}$ in $\bar{A} B C C 1$ and $-15281-15278 \mathrm{CTCT}>$ delete in $A B C B 11$. Interestingly, all the genes encode 
ABC transporters, suggesting that efflux transporting systems, which could be involved in protecting tissues from the accumulation of xenobiotics and resulting toxicity, play an important role in the development of HCC.

Among various SNPs in the $A B C B 1$ gene, $3435 \mathrm{C}>\mathrm{T}$, a synonymous variant, has been investigated in greatest detail in humans [8,14]. Using an immunochemical approach to quantify P-glycoprotein content, Hoffmeyer et al. [35] found that 3435C $>\mathrm{T}$ was associated with a significantly reduced intestinal P-glycoprotein content in subjects with the $\mathrm{T} / \mathrm{T}$ genotype. However, the association of $3435 \mathrm{C}>\mathrm{T}$ with expression (both at the protein and mRNA levels) and in vivo transport activity (including human studies) is controversial, with increased, decreased, and unchanged expression/transport being reported [14]. Therefore, epigenetic concerns have been introduced into the experiments in order to assess the confounding results. Recently, Wang et al. [36] reported that the $3435 \mathrm{C}>\mathrm{T}$ variant was associated with an allelic expression imbalance due to decreasing mRNA stability, leading to decreasing hepatic ABCB1 mRNA levels. On the other hand, Kimchi-Sarfaty et al. [37] reported that $3435 \mathrm{C}>\mathrm{T}$ altered the substrate specificity of P-glycoprotein. They hypothesized that the variant changes the mRNA translation rate and thereby affected protein folding.

$825 \mathrm{~T}>\mathrm{C}$ in $A B C C 1$ and $-15281-15278 \mathrm{CTCT}>\mathrm{de}-$ lete in $A B C B 11$ were synonymous and promoter variants, respectively. Thus, none of the three candidate variants including $3435 \mathrm{C}>\mathrm{T}$ in $A B C B 1$ in the combination study had an influence on the amino acid sequence in each transporter protein. Similar to $825 \mathrm{~T}>\mathrm{C}$, the effect of $-15281-15278 \mathrm{CTCT}>$ delete on transport activity has not yet been well investigated. One luciferase gene reporter experiment indicated that promoter constructs including -15281_-15278CTCT > delete were not associated with changes in luciferase activity [18]. All three candidate variants could be detected at relatively high frequency even in the healthy subjects, casting doubt on a significant contribution to the risk of developing $\mathrm{HCC}$; however, a role for these variants in HCC cannot be excluded. Based on the present findings, a single mutation may not be involved in HCC under normal conditions, but combined with another mutation, may increase susceptibility to HCC. Indeed, there is substantial evidence that p-glycoprotein and MRP1 have overlapping functions in tissue defense [5]. Although each transporter alone would not have sufficient transport capability, together they are likely to provide protection against the accumulation of carcinogen(s).

Some carcinogenic substances may undergo activation or inactivation by hepatic enzymes. This may introduce a bias in the study, because the difference attributed to
ABC-transporters may arise in fact from metabolizing enzymes. Further studies including polymorphisms of genes encoding hepatic metabolizing enzymes such as cytochrome P450 (CYP) 2D6 and CYP3A5 are required.

There are some limitations of the present study. We genotyped various SNPs that have been shown to be most functionally significant in previous pharmacogenomic studies or observed at relatively high frequencies without ethnic diversity. However, since the genotypes investigated here were not based on known phenotypes, the usefulness of the results may be limited at this stage. Furthermore, the numbers of enrolled patients and healthy subjects were small (around sixty), and the study had insufficient statistical power to detect even though a large differences in gene frequency between the two groups. Therefore, this study represents a preliminary comparison of frequencies of possible SNPs. Further studies to confirm the association of the SNPs with HCC and how these polymorphisms are associated with phenotypic differences are warranted in a large population study."

In conclusion, the present study suggests that some SNPs of the ABC transporter genes such as $A B C B 1$, $A B C B 11$, and $A B C C 1$ are associated with the susceptibility of developing $\mathrm{HCC}$, implying that aberrant hepatic clearance of toxic substances may increase the risk of hepatocarcinogenesis.

\section{Acknowledgements}

This study was supported by grants from the Ministry of Education, Culture, Sports, Science and Technology, Japan.

\section{REFERENCES}

[1] H. Tsukuma, T. Hiyama, S. Tanaka, M. Nakao, T. Yabuuchi, T. Kitamura, K. Nakanishi, I. Fujimoto, A. Inoue, H. Yamazaki and T. Kawashima, "Risk Factors for Hepatocellular Carcinoma among Patients with Chronic Liver Disease," The New England Journal of Medicine, Vol. 328, No. 12, 1993, pp. 1797-1801.

[2] I. Saito, T. Miyamura, A. Ohbayashi, H. harada, T. Katayama, S. Kikuchi, Y. Watanabe, S. Koi, M. Onji, Y. Ohta, Q.-L. Choo, M. Houghton and G. Kuo, "Hepatitis C Virus Infection is Associated with the Development of Hepatocellular Carcinoma," Proceedings of the National Academy of Sciences of the United States of America, Vol. 87, No. 17, 1990, pp. 6547-6549.

[3] H. Oka, N. Kurioka, K. Kim, T. Kanno, T. Kuroki, Y. Mizoguchi and K. Kobayashi, "Prospective Study of Early Detection of Hepatocellular Carcinoma in Patients with Cirrhosis," Hepatology, Vol. 12, No. 4, 1990, pp. 680-687.

[4] K. Kiyosawa, T. Umemura, T. Ichijo, A. Matsumoto, K. Yoshizawa, A. Gad and E. Tanaka, "Hepatocellular Car- 
cinoma: Recent Trends in Japan," Gastroenterology, Vol. 127, No. (Suppl. 1), 2004, pp. S17-S26.

[5] E. M. Leslie, R. G. Deeley and S. P. Cole, "Multidrug Resistance Proteins: Role of P-Glycoprotein, MRP1, MRP2, and BCRP (ABCG2) in Tissue Defense," Toxicology and Applied Pharmacology, Vol. 204, No. 3, 2005, pp. 216-237.

[6] L. R. Ferguson and S. de Flora, "Multiple Drug Resistance, Antimutagenesis and Anticarcinogenesis," Mutation Research, Vol. 591, No. 1-2, 2005, pp. 24-33.

[7] G. C. Yeh, J. Lopaczynska, C. M. Poore and J. M. Phang, "A New Functional Role for P-Glycoprotein: Efflux Pump for Benzo(Alpha)Pyrene in Human Breast Cancer MCF-7 Cells," Cancer Research, Vol. 52, No. 23, 1992, pp. 6692-6695.

[8] I. Ieiri, H. Takane, T. Hirota, K. Otsubo and S. Higuchi, "Genetic Polymorphisms of Drug Transporters: Pharmacokinetic and Pharmacodynamic Consequences in Pharmacotherapy," Expert Opinion on Drug Metabolism \& Toxicology, Vol. 2, No. 5, 2006, pp. 651-674.

[9] S. Sookoian, G. Castano, A. Burgueno, T. F. Gianotti and C. J. Pirola, "Association of the Multidrug-ResistanceAssociated Protein Gene (ABCC2) Variants with Intrahepatic Cholestasis of Pregnancy," Journal of Hepatology, Vol. 48, No. 1, 2008, pp. 125-132.

[10] L. I. Hu, X. X. Wang, X. Chen, J. Chang, C. Li, Y. Zhang, J. Yang, W. Jiang and S. M. Zhuang, "BCRP Gene Polymorphisms are Associated with Susceptibility and Survival of Diffuse Large B-Cell Lymphoma," Carcinogenesis, Vol. 28, No. 8, 2007, pp. 1740-1744.

[11] Y. Korenaga, K. Naito, N. Okayama, H. Hirata, Y. Suehiro, Y. Hamanaka, H. Matsuyama and Y. Hinoda, "Association of the BCRP C421A Polymorphism with Nonpapillary Renal Cell Carcinoma," International Journal of Cancer, Vol. 117, No. 3, 2005, pp. 431-434.

[12] M. Tanabe, I. Ieiri, N. Nagata, K. Inoue, S. Ito, Y. Kanamori, M. Takahashi, Y. Kurata, J. Kigawa, S. Hoguchi, N. Terakawa and K. Otsubo, "Expression of P-Glycoprotein in Human Placenta: Relation to Genetic Polymorphism of the Multidrug Resistance (MDR)-1 Gene," Journal of Pharmacology and Experimental Therapeutics, Vol. 297, No. 3, 2001, pp. 1137-1143.

[13] G. D. Leschziner, T. Andrew, M. Pirmohamed and M. R. Johnson, “ABCB1 Genotype and PGP Expression, Function and Therapeutic Drug Response: A Critical Review and Recommendations for Future Research," The Pharmacogenomics Journal, Vol. 7, No. 3, 2007, pp. 154-179.

[14] I. Ieiri, H. Takane and K. Otsubo, "The MDR1 (ABCB1) Gene Polymorphism and its Clinical Implications," Clinical Pharmacokinetics, Vol. 43, No. 9, 2004, pp. 553576.

[15] S. Ito, I. Ieiri, M. Tanabe, A. Suzuki, S. Higuchi and K. Otsubo, "Polymorphism of the ABC Transporter Genes, MDR1, MRP1 and MRP2/cMOAT, in Healthy Japanese Subjects," Pharmacogenetics, Vol. 11, No. 2, 2001, pp. 175-184.

[16] H. Fukushima-Uesaka, Y. Saito, K. Maekawa, R. Hase- gawa, K. Suzuki, T. Yanagawa, H. Kajio, N. Kuzuya, M. Noda, K. Yasuda, M. Tohkin and J. Sawada, "Genetic Variations of the ABC Transporter Gene ABCC3 in a Japanese Population," Drug Metabolism and Pharmacokinetics, Vol. 22, No. 2, 2007, pp. 129-135.

[17] D. Kobayashi, I. Ieiri, T. Hirota, H. Takane, S. Maegawa, J. Kigawa, H. Suzuki, E. Nanba, M. Oshimura, N. Terakawa, K. Otsubo, K. Mine and Y. Sugiyama, "Functional Assessment of ABCG2 (BCRP) Gene Polymorphisms to Protein Expression in Human Placenta," Drug Metabolism and Disposition, Vol. 33, No. 1, 2005, pp. 94-101.

[18] T. Lang, M. Haberl, D. Jung, A. Drescher, R. Schlagenhaufer, A. Keil, E. Mornhinweg, B. Stieger, G. A. KullakUblick and R. Kerb, "Genetic Variability, Haplo- type Structures, and Ethnic Diversity of Hepatic Trans- porters MDR3 (ABCB4) and Bile Salt Export Pump (ABCB11)," Drug Metabolism and Disposition, Vol. 34, No. 9, 2006, pp. 1582-1599.

[19] T. Gerloff, B. Stieger, B. Hagenbuch, J. Madon, L. Landmann, J. Roth, A. F. Hoffmann and P. J. Meier, "The Sister of P-Glycoprotein Represents the Canalicular Bile Salt Export Pump Of Mammalian Liver," The Journal of Biological Chemistry, Vol. 273, No. 16, 1998, pp. 1004610050.

[20] R. Wang, M. Salem, I. M. Yousef, B. Tuchweber, P. Lam, S. J. Childs, C. D. Helgason, C. Ackerley, M. J. Phillips and V. Ling, "Targeted Inactivation of Sister of P-Glycoprotein Gene (spgp) in Mice Results in Nonprogressive but Persistent Intrahepatic Cholestasis," Proceedings of the National Academy of Sciences of the United States of America, Vol. 98, No. 4, 2001, pp. 2011-2016.

[21] S. S. Strautnieks, L. N. Bull, A. S. Knisely, S. A. Kocoshis, N. Dahl, H. H. Arnell, E. Sokal, K. Dahan, S. Childs, V. Ling, M. S. Tanner, A. F. Kagalwalla, A. Nemeth, J. Pawlowska, A. Baker, G. Mieli-Vergani, N. B. Freimer, R. M. Gardiner and R. J. Thompson, "A Gene Encoding a Liver-Specific ABC Transporter is Mutated in Progressive Familial Intrahepatic Cholestasis," Nature Genetics, Vol. 20, No. 3, 1998, pp. 233-238.

[22] P. L. Jansen, S. S. Strautnieks and E. Jacquemin, "Hepatocanalicular Bile Salt Export Pump Deficiency in Patients with Progressive Familial Intrahepatic Cholestasis," Gastroenterology, Vol. 117, No. 6, 1999, pp. 1370-1379.

[23] E. M. Leslie, K. Ito, P. Upadhyaya, S. S. Hecht, R. G. Deeley and S. P. Cole, "Transport of the Beta-O-Glucuronide Conjugate of the Tobacco-Specific Carcinogen4-(Methylnitrosamino)-1-(3-Pyridyl)-1-Butanol (NNAL) by the Multidrug Resistance Protein 1 (MRP1). Requirement for Glutathione or a Non-Sulfur-Containing Analog," The Journal of Biological Chemistry, Vol. 276, No. 30, 2001, pp. 27846-27854.

[24] A. E. van Herwaarden, J. W. Jonker, E. Wagenaar, R. F. Brinkhuis, J. H. M. Schellens, J. H. Beijnen and A. H. Schinkel, "The Breast Cancer Resistance Protein (Bcrp1/ Abcg2) Restricts Exposure to the Dietary Carcinogen2-Amino-1-Methyl-6-Phenylimidazo[4,5-b]Pyridine," Cancer Research, Vol. 63, No. 19, 2003, pp. 6447-6452.

[25] M. Siegsmund, U. Brinkmann, E. Scháffeler, G. Weirich, 
M. Schwab, M. Eichelbaum, P. Fritz, O. Burk, J. Decker, P. Alken, U. Rothenoieler, R. Kerb, S. Hoffmeyer and S. Brauch, "Association of the P-Glycoprotein Transporter MDR1(C3435T) Polymorphism with the Susceptibility to Renal Epithelial Tumors," Journal of the American Society of Nephrology, Vol. 13, No. 7, 2002, pp. 1847-1854.

[26] U. Potocnik, D. Glavac and M. Dean, "Common Germline MDR1/ABCB1 Functional Polymorphisms and Haplotypes Modify Susceptibility to Colorectal Cancers with High Microsatellite Instability," Cancer Genetics and Cytogenetics, Vol. 183, No. 1, 2008, pp. 28-34.

[27] T. E. Massey, R. K. Stewart, J. M. Daniels and L. Liu, "Biochemical and Molecular Aspects of Mammalian Susceptibility to Aflatoxin B1 Carcinogenicity," Proceedings of the Society for Experimental Biology and Medicine, Vol. 208, No. 3, 1995, pp. 213-227.

[28] D. W. Loe, R. K. Stewart, T. E. Massey, R. G. Deeley and S. P. Cole, "ATP-Dependent Transport of Aflatoxin B1 and its Glutathione Conjugates by the Product of the Multidrug Resistance Protein (MRP) Gene," Molecular Pharmacology, Vol. 51, No. 6, 1997, pp. 1034-1041.

[29] A. Lorico, J. Nesland, E. Emilsen, O. Fodstad and G. Rappa, "Role of the Multidrug Resistance Protein 1 Gene in the Carcinogenicity of Aflatoxin B1: Investigations Using MRP1-Null Mice," Toxicology, Vol. 171, No. 2, 2002, pp. 201-205.

[30] E. Ros, L. Libbrecht, M. Geuken, P. L. Jansen and T. A. Roskams, "High Expression of MDR1, MRP1, and MRP3 in the Hepatic Progenitor Cell Compartment and Hepatocytes in Severe Human Liver Disease," Journal of Pathology, Vol. 200, No. 5, 2003, pp. 553-560.

[31] S. Bonin, L. Pascolo, L. S. Crocé, G. Stanta and C. Tiribelli, "Gene Expression of ABC Proteins in Hepatocellular Carcinoma, Perineoplastic Tissue, and Liver Diseases," Molecular Medicine, Vol. 8, No. 4, 2002, pp. 318-325.

[32] G. A. Meijer, A. B. Schroeijers, M. J. Flens, S. G. Meu- wissen, P. van der Valk, J. P. A. Baak and R. J. Scheper, "Increased Expression of Multidrug Resistance Related Proteins PGP, MRP1, and LRP/MVP Occurs Early in Colorectal Carcinogenesis," Journal of Clinical Pathology, Vol. 52, No. 6, 1999, pp. 450-454.

[33] A. S. Knisely, S. S. Strautnieks, Y. Meier, B. Stieger, J. A. Byne, B. C. Portmann, L. N. Bull, L. Pawlikowska, B. Bilezikçi, F. Özçay, A. László, L. Tiszlavicz, L. Moore, J. Raftos, H. Arnell, B. Fischer, A. Németh, N. Papadogiannakis, J. Cielecka-Kuszyk, I. Jankowska, J. Pawlowska, H. Melín-Aldana, K. M. Emerick, P. F. Whitington, G. MieliVergani and R. J. Thompson, "Hepatocellular Carcinoma in Ten Children under Five Years of Age with Bile Salt Export Pump Deficiency," Hepatology, Vol. 44, No. 2, 2006, pp. 478-486.

[34] H. Bernstein, C. Bernstein, C. M. Payne, K. Dvorakova and H. Garewal, "Bile Acids as Carcinogens in Human Gastrointestinal Cancers," Mutation Research, Vol. 589, No. 1, 2005, pp. 47-65

[35] S. Hoffmeyer, O. Burk, O. von Richter, H. P. Arnold, J. Brockmöller, A. Johne, I. Cascorbi, T. Gerloff, I. Roots, M. Eichelbaum and U. Brinkmann, "Functional Polymorphisms of the Human Multidrug-Resistance Gene: Multiple Sequence Variations and Correlation of One Allele with P-Glycoprotein Expression and Activity in vivo," Proceedings of the National Academy of Sciences of the United States of America, Vol. 97, No. 7, 2000, pp. 3473-3478.

[36] D. Wang and W. Sadée, "Searching for Polymorphisms that Affect Gene Expression and mRNA Processing: Example ABCB1 (MDR1)," The AAPS Journal, Vol. 8, No. 3, 2006, pp. E515-E520.

[37] C. Kimchi-Sarfaty, J. M. Oh, I. W. Kim, Z. E. Sauna, A. M. Calcagno, S. V. Ambudkar and M. M. Gottesman, "A 'Silent' Polymorphism in the MDR1 Gene Changes Substrate Specificity," Science, Vol. 315, No. 5811, 2007, pp. 525-528. 